\title{
Evaluation of the anti-candidal activity of methanolic leaf extract of cleistopholis patens (fam. Annonaceae) on candida species isolated from stage II HIV patients.
}

\author{
David C Okechukwu ${ }^{1}$, Mumuni A. Momoh ${ }^{1}$, Charles O Esimone ${ }^{2}$
}

\begin{abstract}
1. Pharmaceutical Microbiology Unit of Department of Pharmaceutics, Faculty of Pharmaceutical Sciences University of Nigeria, Nsukka,Enugu State, Nigeria.

2. Department of Pharmaceutical Microbiology and Biotechnology Nnamdi Azikiwe University, Awka, Anambra State, Nigeria.
\end{abstract}

\begin{abstract}
Background: Candida species (sp) is implicated in causing opportunistic disseminated mycotic complications in stage II HIV patients. Cleistopholis patens is a West African medicinal tree reported to have significant antifungal activity against C. albicans.

Objectives: This study aimed to determine the anti-candidal activity of methanolic leaf extract of Cleistopholis patens against Candida species isolated from stage II HIV patients.

Methods: The minimum inhibitory concentration (MIC) of the extract and Nystatin ${ }^{\circledR}$ was determined by agar dilution method. The killing rate studies of the plant extract and Nystatin ${ }^{\circledR}$ were also determined.

Results: The extract had activity against all Candida isolates, with the MIC against the five isolates ranging from $6.0-9.8$ $\mathrm{mg} / \mathrm{ml}$. Nystatin ${ }^{\circledR}$ also demonstrated plausible activity against the isolates with MICs ranging from $0.3125-25 \mathrm{mg} / \mathrm{ml}$. Candida albicans strain 2 was the most sensitive to both extract and Nystatin ${ }^{\circledR}$ with MIC values of 6 and $0.3125 \mathrm{mg} / \mathrm{ml}$ respectively. Candida krusei was the least sensitive with MIC values of 9.8 and $25 \mathrm{mg} / \mathrm{ml}$ for the extract and Nystatin ${ }^{\circledR}$ respectively. The killing rate values for the extract ranged from -0.029 to $-0.091 \mathrm{~min}^{-1}$ and that of Nystatin ${ }^{\circledR}$ ranged from -0.076 to $-0.112^{16} \mathrm{~min}^{-1}$.
\end{abstract}

Conclusions: The results indicate that the methanolic extract of Cleistopholis patens is a promising clinical alternative besides Nystatin ${ }^{\circledR}$ in the treatment of infections caused by Candida species in stage II HIV patients.

Keywords: Anti-candidal activity, Cleistopholis patens, Candida, HIV Patients.

DOI: http://dx.doi.org/10.4314/ahs.v15i3.12

Cite as: Okechukwu DC, Momoh MA, Esimone CO. Evaluation of the anti-candidal activity of methanolic leaf extract of cleistopholis patens (fam. Annonaceae) on candida species isolated from stage II HIV patients. Afri Health Sci. 2015;15(3):789-96. doi: bttp:// dx.doi. org/10.4314/abs.v15i3.12

\section{Introduction}

There is need for new effective and less toxic antifungal antibiotics for the treatment of disseminated mycotic infections in the light of the significant toxicities, failure rates of the currently available systemic antifungal agents and emergence of resistant strains of fungi for instance Candida sp implicated in opportunistic disseminated mycotic complications in stage II HIV patients ${ }^{1}$. These events further heightened the search for new alternative drugs of plant origin in combating opportunistic mycotic infections associated with stage II

\section{Corresponding author: \\ David C Okechukwu \\ Division of Pharmaceutical Microbiology \\ Department of Pharmaceutics \\ Faculty of Pharmaceutical Sciences \\ University of Nigeria, Nsukka. \\ E-mail: david.okechukwu@unn.edu.ng \\ Tel: +2348033391478}

HIV infection ${ }^{2}$. Discovery of new antimicrobials has relied primarily upon isolation of such agents from natural sources ${ }^{3}$. This search was extended to the leaves of the plant Cleistopholis patens (Benth.) Engl. \& Diels found distributed in various parts of tropical Africa, in the rain forest region such as Burkina Faso, Cote d' ivoire, Ghana, Liberia ,Sierra Leone, Togo and Nigeria ${ }^{4}$. It is a small to medium sized tree up to $27 \mathrm{~m}$ high of secondary and swamp forest with distinctive airy crown of horizontal branches and branchlets with well dispersed leaves resembling compound leaves ${ }^{5,6}$. A new alkaloid (3-methoxysampangine) which exhibited significant activity against Candida albicans, Aspergillus fumigatus, and Cryptococcus neoformans was isolated from the root bark of Cleistopholis patens ${ }^{1}$. The anti-plasmodial activity of nonvolatile and volatile extract from the stem bark of Cleistopholis patens had been reported ${ }^{7,8}$. According to ethno medicinal report the stem bark of the plant is used in the treatment of jaundice ${ }^{9}$, infective hepatitis and stomach disorders ${ }^{10}$. The roots are used as a vermifurge ${ }^{10}$ and the leaves are said to remedy fever ${ }^{11}$. 
This paper describes the anti-candidal activity of the leaves of Cleistopholis patens (Benth.) Engl.\& Diels.

\section{Materials and methods \\ Test microorganisms}

Test microorganisms used were four strains of Candida albicans and a strain of Candida krusie previously isolated from stage II HIV patients visiting University of $\mathrm{Ni}$ geria of Teaching Hospital Enugu. The Candida spp were isolated using the method described by Jagdev and Arora $^{12}$. Two oral swabs were collected from each patient under sterile conditions. One swab was used for Gram staining and $\mathrm{KOH}$ wet mount and other swab was inoculated on Sabouraud's dextrose agar (SDA) with chloramphenicol and incubated at $25^{\circ} \mathrm{C}$. All the cultures were observed every day for a week for the appearance of colonies suggestive of yeast like organism. The various isolates were identified and characterized at the mycology laboratory of the Department of Microbiology University of Nigeria, Nsukka using standard methods described by Larone ${ }^{13}$.

\section{Plant material}

The leaves of Cleistopholis patens were collected from Nsukka in Enugu state between the months of May and June. The leaves were authenticated by Mr. Alfred Ozioko the taxonomist at the International Centre for Ethnomedicine and Drug Development, Nsukka where a voucher specimen with voucher number INTERCEDD/505 was kept in the herbarium for future reference.

\section{Extraction solvents and other materials}

Analytical grade of methanol (BDH, England) was used. Other materials used include Nystatin ${ }^{\circledR}$, Sabouraud's dextrose agar (SDA) (Oxoid, England), Dimethylsulphoxide (DMSO) (BDH, England) and chloramphenicol (Fidson, Nigeria).

\section{Extraction of cleistopholis patens}

The collected leaves were shade dried and milled. The powder was cold macerated in methanol and allowed to stand overnight. It was then clarified with the aid of cotton wool. Subsequently the methanol extract was evaporated to dryness and stored in a refrigerator.

\section{Collection of test microorganisms}

Slant cultures of test fungi were obtained from the Mycology laboratory of the Department of Microbiology University of Nigeria. The inoculated slants were incu- bated at $25^{\circ} \mathrm{C}$ for three days, and subsequently stored in a refrigerator.

\section{Standardization of test microorganisms}

A loopful of the SDA slant cultures above was obtained and introduced into a sterile test tube containing $5 \mathrm{ml}$ sterile distilled water. The volume was adjusted by dilution to obtain cell population of $1.0 \times 10^{6} \mathrm{cfu} / \mathrm{ml}$ equivalent to $1.0 \mathrm{McF}$ arland standard.

\section{Preliminary sensitivity test of extract and Nysta- $\operatorname{tin}{ }^{\circledR}$}

A modification of the agar dilution method described by Esimone et $\mathrm{al}^{14}$ was used. Exactly $1.5 \mathrm{~g}$ of the dried methanolic extract was dissolved in $15 \mathrm{ml}$ of Dimethylsulphoxide (DMSO) to obtain a stock concentration of $100 \mathrm{mg} / \mathrm{ml}$. Subsequently $0.5,1$ and $2 \mathrm{ml}$ of the stock concentration were diluted with $9.5,9$ and $8 \mathrm{ml}$ of sterile molten SDA in three sterile petri dishes respectively. The following concentrations were obtained namely 5,10 and $20 \mathrm{mg} / \mathrm{ml}$. The setup was thoroughly mixed by swirling and allowed to set, after which the SDA plates were dried in the dryer at $37^{\circ} \mathrm{C}$ for $1 \mathrm{hr}$. Thereafter the SDA plates were inoculated with the test organisms and incubated at $25^{\circ} \mathrm{C}$ for $24 \mathrm{hrs}$ after which the results were recorded. The method was repeated for Nystatin ${ }^{\circledR}$ against the test isolates. However $0.5,1.5$, and $2.5 \mathrm{ml}$ of stock concentration of Nystatin $\AA$ of $100 \mathrm{mg} / \mathrm{ml}$ were diluted with $9.5,8.5$ and $7.5 \mathrm{ml}$ of sterile molten SDA in three sterile petri dishes to obtain concentrations of 5,15 , and $25 \mathrm{mg} / \mathrm{ml}$ of Nystatin ${ }^{\circledR}$.

\section{Minimum Inhibitory Concentration (MIC) of extr act}

A modification of the agar dilution method described by Esimone et al ${ }^{14}$ was used. Arithmetic serial dilutions of $100 \mathrm{mg} / \mathrm{ml}$ stock concentration of extract were made using sterile molten SDA to obtain final agar concentrations ranging from 5 to $20 \mathrm{mg} / \mathrm{ml}$. The plates were allowed to set after which they were dried at $37^{\circ} \mathrm{C}$ for $1 \mathrm{hr}$. Thereafter the plates were streaked with the test microorganisms and incubated at $25^{\circ} \mathrm{C}$ for $24 \mathrm{hrs}$. The MIC of the extract was determined.

\section{Minimum Inhibitory Concentration (MIC) of Nystatin ${ }^{\circledR}$}

The same method described above was similarly employed to determine the MIC of Nystatin ${ }^{\circledR}$. 
Determination of the killing rate of extract and Nystatin ${ }^{\circledR}$

A modification of the killing rate method described by Iroha et $\mathrm{al}^{15}$ was used. Exactly $1 \mathrm{ml}$ of standardized culture of the fungi $\left(1 \times 10^{6} \mathrm{cfu} / \mathrm{ml}\right.$ equivalent to 1.0 McFarland's standard) was inoculated into test tubes containing $9 \mathrm{ml}$ of the antimicrobial agents (extract or Nystatin ${ }^{\circledR}$ in concentration thrice their MIC values) in double strength SDA. Prior to viable cell count determination, the antimicrobial effect of the extract or Nystatin ${ }^{\circledR}$ in the samples withdrawn at various time intervals was terminated by diluting the withdrawn samples 1000 folds. Thereafter the viable count was determined using the surface viable count method.

\section{Statistical analysis}

The statistical analysis of the MICs and killing rate values for extract and Nystatin ${ }^{\circledR}$ was done with SPSS (version 20). Data was tested for statistical significance using Student's independent samples T-test and differences were considered significance at $\mathrm{P}<0.05$.

\section{Results}

\section{Preliminary sensitivity test results}

Result of the preliminary sensitivity test shown in Table 1 indicated that the plant extract had activities against test organisms down to the concentration of $10 \mathrm{mg} / \mathrm{ml}$. No growth inhibition was observed for all the test organisms at the concentration of $5 \mathrm{mg} / \mathrm{ml}$.

\section{Table 1: Sensitivity results of Candida isolates to Extract and Nystatin ${ }^{\circledR}$}

\begin{tabular}{llcc} 
& & \multicolumn{2}{c}{ Concentration $(\mathrm{mg} / \mathrm{ml})$} \\
$\mathrm{S} / \mathrm{N}$ & Organism & Nystatin & \\
1 & Candida albicans & 10 & 5 \\
2 & Candida albicans & 10 & 5 \\
3 & Candida albicans & 10 & 5 \\
4 & Candida albicans & 10 & 5 \\
5 & Candida krusei & 10 & 25
\end{tabular}

Key: - = Growth inhibition: + = No growth inhibition

Furthermore all isolates except Candida krusei were sensitive to Nystatin ${ }^{\circledR}$ down to $5 \mathrm{mg} / \mathrm{ml}$. Candida krusei was sensitive at the concentration of $25 \mathrm{mg} / \mathrm{ml}$ but resistant at 15 and $5 \mathrm{mg} / \mathrm{ml}$ respectively.

\section{MIC Determination of Plant Extract and Nystatin ${ }^{\circledR}$}

The MIC values (Table 2) of the plant extract ranged from $6-9.8 \mathrm{mg} / \mathrm{ml}$. The highest MIC value was recorded against Candida krusei whereas Candida albicans strain 2 had the lowest MIC value for the plant extract. The MIC values of Nystatin ${ }^{\circledR}$ against these isolates ranged from $0.3125-25 \mathrm{mg} / \mathrm{ml}$. The highest MIC value for Nystatin ${ }^{\circledR}$ was obtained against Candida krusei and the lowest value was recorded against Candida albicans strain 2 as indicated in the table. Strains 1, 2, and 4 of Candida albicans were more sensitive to Nystatin ${ }^{\circledR}$ at lower concentrations than they were to the plant extract. Furthermore Candida albicans strain 3 was more sensitive to the plant extract than to Nystatin ${ }^{\circledR}$. 
Table 2: Minimum inhibitory concentration of plant extract and Nystatin ${ }^{\circledR}$ against Candida isolates

Concentration $(\mathrm{mg} / \mathrm{ml})$

$\begin{array}{llll}\mathrm{S} / \mathrm{N} & \text { Organism } & \text { Extract } & \text { Nystatin }^{\circledR} \\ 1 & \text { Candida albicans } & 7.0 \pm 1.00 & 2.5 \pm 0.00 \\ 2 & \text { Candida albicans } & 6.0 \pm 1.00 & 0.3125 \pm 22.0 \\ 3 & \text { Candida albicans } & 9.0 \pm 2.00 & 22.0 \pm 2.00 \\ 4 & \text { Candida albicans } & 9.4 \pm 0.40 & 0.625 \pm 0.00 \\ 5 & \text { Candida krusei } & 9.8 \pm 0.10 & 25.0 \pm 2.65\end{array}$

Also Candida albicans strains 3 and 5 were more susceptible to Nystatin ${ }^{\circledR}$ at higher concentrations of 22 and $25 \mathrm{mg} / \mathrm{ml}$ than they were to the plant extract. The statistical analysis showed that there was significant difagainst time for extract.

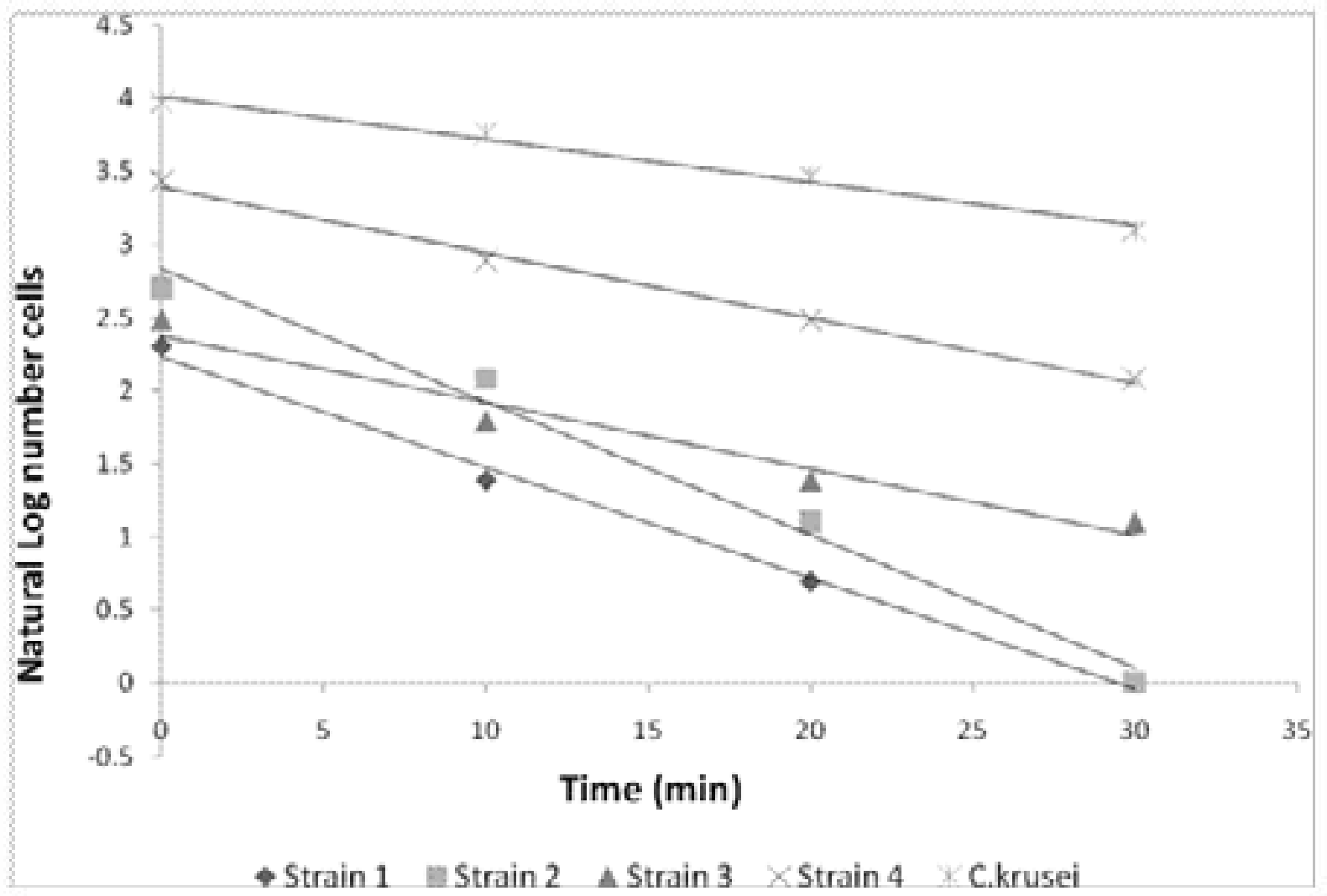

ference at $\mathrm{P}<0.05$ between the MICs of the plant extract and Nystatin ${ }^{\circledR}$ against Candida isolates.

Killing rate study of plant extract and Nystatin ${ }^{\circledR}$ The results of the killing rate study of the plant extract and Nystatin ${ }^{\circledR}$ are shown in Figures 1-3.

\section{Figure 1. Plot of natural $\log$ number of survivor cells of $C$. albicans strains 1-4, and C. krusei}


Figure 2. . Plot of Log number of survivor cells of C. albicans strains 1,2, and C. krusei against time for Nystatin ${ }^{\circledR}$.

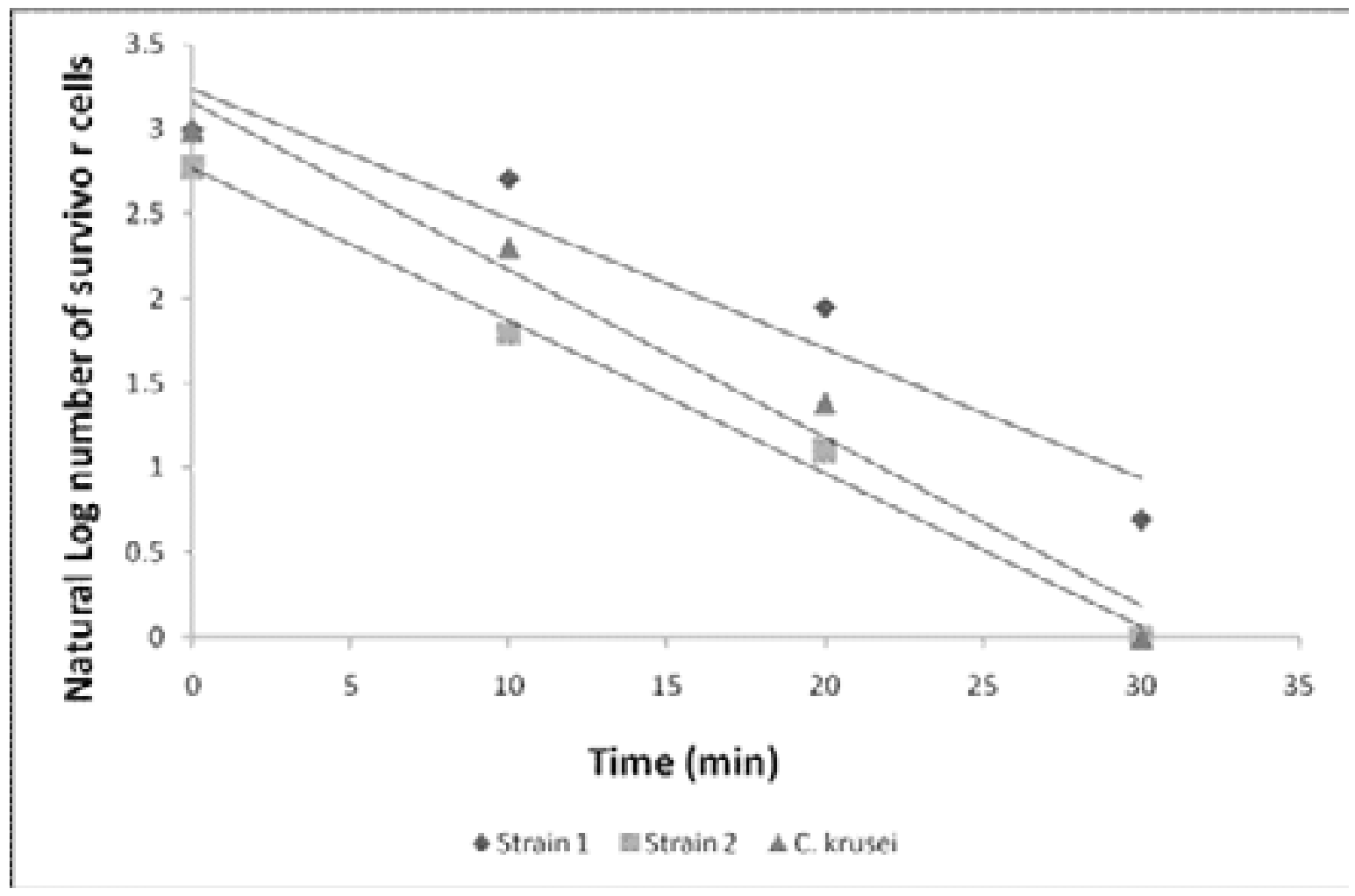

Figure 3. Plot of Log number of survivor cells of Candida albicans strains 3 and 4 against time for Nystatin ${ }^{\circledR}$.

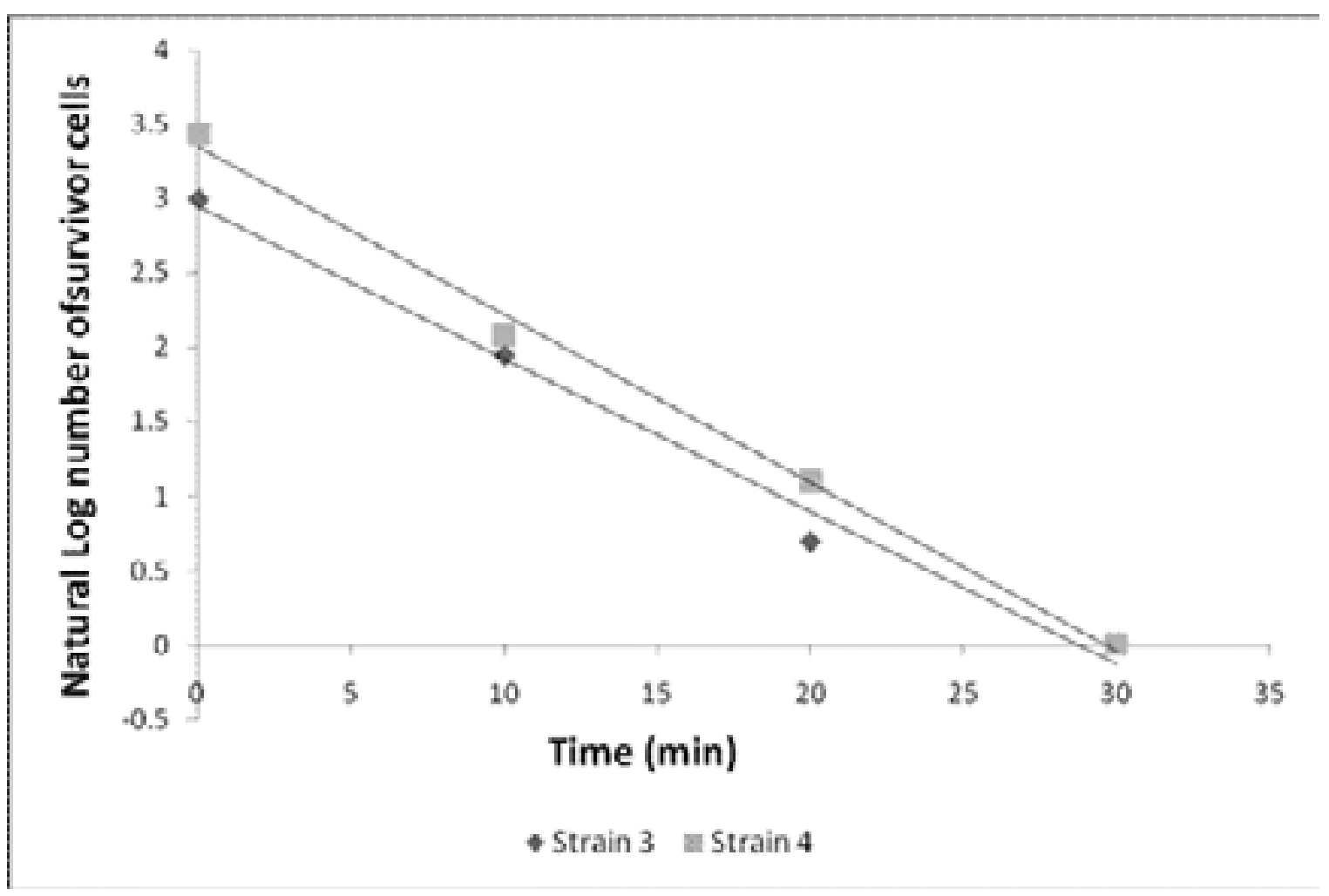


The general formula used to express the rate at which a specified concentration or amount of an antimicrobial agent kills microbial cells in a population is given by In $\mathrm{Nt}=\mathrm{In} \mathrm{N0}-\mathrm{Kt}$ where $\mathrm{K}$ represents the death rate constant or rate of kill of the antimicrobial agent.

\section{Table 3: The values of the slopes (rate of kill) and $R^{2}$ for the extract and Nystatin ${ }^{\circledR}$ on the isolates}

Slope values

$\mathrm{S} / \mathrm{N}$ Isolates

1 Candida albicans

$\operatorname{Extract}\left(\mathrm{min}^{-1}\right)$

Nystatin ${ }^{\circledR}\left(\min ^{-1}\right)$

Extract

$\mathrm{R}^{2}$ Values

2 Candida albicans

$-0.076 \pm 0.002$

$-0.076 \pm 0.001$

0.994

0.986

0.960

0.994

0.984
Nystatin ${ }^{\circledR}$

0.926

0.993

0.988

0.995

0.975
It is obtained as the slope when Log number of survivors is plotted against time (t). The values of the $\mathrm{R} 2$ and slopes (rate of kill) for the extract and Nystatin ${ }^{\circledR}$ deduced from Figures 1-3 are shown in Table 3.

The rate of kill of the extract against the Candida isolates ranged from -0.029 to $-0.091 \mathrm{~min}^{-1}$ and that of Nystatin ${ }^{\circledR}$ ranged from -0.076 to $-0.112 \mathrm{~min}^{-1}$. The killing rate value for the extract against strain 2 is slightly higher than that of Nystatin ${ }^{\circledR}$. Nystatin $\AA$ recorded higher killing rate values against the rest of the isolates than the extract except for Candida albicans strain 1 in which the values were the same. Also the killing rate values of Nystatin ${ }^{\circledR}$ against strains 3 and 4 of Candida albicans were more than twice the values of the killing rate of the extract against the same organisms. In the case of Candida krusei, the killing rate value for Nystatin ${ }^{\circledR}$ was more than thrice the value obtained for the extract against the same organism. However the killing rate values of the extract against Candida albicans strain $4\left(-0.044 \mathrm{~min}^{-1}\right)$ and strain $3\left(-0.045 \mathrm{~min}^{-1}\right)$ were very close to each other. There was a significant difference between the killing rates values of the plant extract and Nystatin ${ }^{\circledR}$ against the Candida isolates at $\mathrm{P}<0.05$.

\section{Discussion}

Observations made from the preliminary sensitivity tests results (Table 1) of both the extract and Nystatin $\mathbb{}$ respectively indicated that all Candida species used in the study were sensitive to the extract even at $10 \mathrm{mg} / \mathrm{ml}$ concentration. At $5 \mathrm{mg} / \mathrm{ml}$ all showed resistance to the extract but were all sensitive to Nystatin ${ }^{\circledR}$ at this concentration except Candida krusei. Furthermore it was observed from the sensitivity result of Nystatin ${ }^{\circledR}$ that all the Candida species used except Candida krusei were sensitive to Nystatin ${ }^{\circledR}$ at $5 \mathrm{mg} / \mathrm{ml}$ concentration. The later was sensitive to Nystatin ${ }^{\circledR}$ only at $25 \mathrm{mg} / \mathrm{ml}$ but manifested resistance at 5 and $15 \mathrm{mg} / \mathrm{ml}$. The activity demonstrated by the methanolic leaf extract of Cleistopholis patens in this study was because of the presence of copious amount of terpenoids, saponins, glycosides, steroids, and alkaloids ${ }^{16}$ which are secondary metabolites with known antimicrobial activity as demonstrated in previous studies by other workers ${ }^{17,18,19,20}$. In addition, the MIC values of Nystatin ${ }^{\circledR}$ against the Candida species except Candida albicans strain 3 and Candida krusei were lower than the MIC values of the extract against these organisms. From our study, infections caused by these Candida species in those HIV patients with the exception of Candida albicans strain 3 and Candida krusei, would be better treated with higher doses of Nystatin ${ }^{\circledR}$ than the extract because of the high MIC

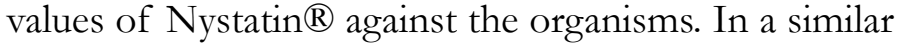
study by Hufford et $\mathrm{al}^{21}$ three anti-candidal constituents were isolated from the root bark of Cleistopholis pat- 
ens. However the MIC of Eupolauridine (one of the constituents isolated) was found to be $1.56 \mu \mathrm{g} / \mathrm{ml}$ which was greater than $0.39 \mu \mathrm{g} / \mathrm{ml}$ the MIC value for amphotericin $\mathrm{B}$ against the three strains of Candida albicans used. Consequently they considered eupolauridine as a promising potential new antifungal drug. The methanolic extract in this present study has a promising potential as a clinical alternative to Nystatin in treatment of infections caused by Candida albicans and Candida krusei. In contrast, it is interesting to note that the MIC value of the extract against Candida albicans strain 3 and Candida krusei was significantly lower than that of Nystatin ${ }^{\circledR}$ (which was more than twice the MICs for the extract). This was deviation from the findings of Hufford et $\mathrm{al}^{1}$. In another study, Liu et $\mathrm{al}^{21}$ isolated a new alkaloid, 3 - methoxysampangine in association with three already known alkaloids from the root bark of Cleistopholis patens which had activity against Candida albicans, Aspergillus fumigatus and Cryptococcus neoformans.

The results from Figure 1 showed that the killing potency of the extract is highest especially against Candida albicans strain 2 whose population was killed within 30 min, followed by strain 1 whose population was killed within less than $30 \mathrm{~min}$. For the rest of the strains, the extract could not kill their entire population within 30 min. It is an established fact that MIC is a measure of the potency of an antimicrobial drug 22 hence the varying potencies of the extract against the strains of Candida spp used in this study reflected the MIC values of the extract against the test Candida strains. Thus small values of MIC of a drug against a microbe signify higher potency ${ }^{22}$. In contrast, Nystatin ${ }^{\circledR}$ exhibited the highest potency against strain 2 killing the entire population within $30 \mathrm{~min}$ (Fig. 2). The next in potency was against strain 4 where the entire population was killed within more than 29 min but less than 30 min (Fig. 3). Nystatin ${ }^{\circledR}$ was less potent against Candida albicans strain 3 and Candida krusei as reflected in the MIC recorded against these organisms.

\section{Conclusion}

The methanolic extract of Cleistopholis patens had significant anti-candidal activity as indicated in its killing potency and MIC values against Candida spp used in this study. Consequently the extract is considered a potential clinical alternative besides Nystatin ${ }^{\circledR}$ in the treatment of infections caused by Candida species in Stage II HIV patients if formulated into a dosage form.
This study highlights among other things the need for continued search for new prototype antimicrobial drugs primarily from higher plant sources, for therein lies the probability of discovery of new drugs relatively free from the challenges of toxicity and cross-resistance associated with present drug therapies. Such discovery will help in addressing opportunistic disseminated mycoses which are common complications of acquired immunodeficiency syndrome.

\section{Acknowledgment}

We acknowledge the assistance of all the technical staff of the Department of Pharmaceutics and Department of Microbiology, University of Nigeria, Nsukka, especially Mr. Kalu Ogboso.

\section{References}

1. Hufford CD, Liu S, Clark AM, Oguntimen BO. Anti-candidal activity of Euplauridine and Onychine alkaloids from Cleistopholis patens. J Nat Prod 1987; 50: 961-964.

2. Oliver-Bever B. Medicinal plants in tropical West Africa.III. Anti-infection therapy with higher plants. J Ethnopharmacol 1983; 9: 1-83.

3. Mitscher LA. New developments in natural products of medicinal interest. Annu Rep Med Chem 1980; 15: 255-266.

4. Hutchison J, Dalziel JM. Annonaceae. In: Keay RWJ, editor. Flora of West Tropical Africa. 2nd ed. London: Crown Agents for Oversea Governments and Administrations; 1954.

5. Le Thomas A. Annonacées. In: Aubreville A, editor. Flore du Gabon. Paris: Muséum National d' Histoire Naturelle; 1969.

6. Verdcourt B. Annonaceae. In: Milne-Redhead CE, Polhill RM, editors. Flora of tropical East Africa. London: Crown Agents for Oversea Governments and Administrations; 1971.

7. Addae-Kyereme J, Croft SL, Kendrick H, Wright CW. Antiplasmodial activities of some Ghanaian plants traditionally used for fever/malaria treatment and of some alkaloids isolated from Pleiocarpa mutica; in vivo antimalarial activity of pleiocarpine. J Ethnopharmacol 2001; 76: 99-103.

8. Boyom FF, Ngouana V, Kemgne EA, et al. Antiplasmodial volatile extracts from Cleistopholis patens Engler \&Diels and Uvariastrum pierreanum Engl. (Engler and Diel (Annonaceae) growing in Cameroon. Parasitol Res 2011; 108 (5): 1211-1217.

9. Addo-Fordjour P, Anning AK, Belford EJD, Akon- 
nor D. Diversity and conservation of medicinal plants in the Bomaa community of the Brong Ahafo region, Ghana. J Med Plant Res 2008; 2 (8): 226-233.

10. Irvine FR. Woody plants of Ghana, with special reference to their uses. London: Oxford University Press; 1961.

11. Dalziel JM. The useful plant of west tropical Africa. London: Crown Agents for the Colonies; 1937.

12. Jagdev M, Arora U. Isolation, characterization and antifungal susceptibility pattern of Candida species causing oropharyngeal candidiasis in HIV positive patients. J Commun Dis 2008; 40 (3): 177-181.

13. Larone DH. Medically important fungi. A guide to identification. 2nd ed. New York: Elsevier Publishers; 1987.

14. Esimone CO, Attama AA, Mundi KS, Ibekwe NN, Chah KF. Antimicrobial activity of Psidium guajava Linn. stem extracts against methicillin-resistant Staphylococcus aureus. Afri J Biotech 2012; 11 (89): 1555615559.

15. Iroha IR, Amadi ES, Orji JO, Esimone CO. In vitro evaluation of the activity of colloidal silver concentrate against Pseudomonas aeruginosa isolated from post- operative wound infection. Sci Res Essay 2008; 3 (5): 209-211.

16. Adonu C, Ugwu OPC, Esimone CO, et al. Phytochemical analyses of the methanol, hot water and n-hexane extracts of the aerial parts of Cassytha filiformis (Linn) and leaves of Cleistopholis patens (Benth).Res J Pharm Bio Chem Sci 2013; 4 (2): 1143 PubMed -1149.

17. Cushnie TPT, Lamb AJ. Antimicrobial activity of flavonoids. Int J Antimicrobial Agents 2005; 26 (5): 343 356.

18. Cowan MW. Plant products as antimicrobial agents. Clin Microbiol Rev 1999; 12: 564 - PubMed ;582.

19. Stary L. The national guide to medicinal herbs and plants. London: Tiger Books International; 1998.

20. Okwu DE, Okwu ME. Chemical composition of Spondias mombin Linn plant parts. I Sustain Agric Environ 2004; 6 (2): 140-147.

21. Liu S, Oguntimein B, Hufford CD, Clark AM. 3-Methoxysampangine, a novel antifungal copyrine alkaloid from Cleistopholis patens. Antimicrob agents and chemo 1990; 34 (4): 529-533.

22. Levison ME. Pharmacodynamics of antimicrobial drugs. Infect Dis Clin N Am 2004; 18: 451-465. 